UDK/UDC: 930.2:003.074(497.6)"1444"

Original research article

Received:7/7/2020

Accepted: 19/11/2020

DOI: $10.46352 / 23036974.2020 .2 .73$

\title{
The 1444 Treaty between King Alfonso V of Aragon and Grand Duke Stjepan Vukčić
}

\author{
ALMIR PECO* \\ Faculty of Philosophy, University of Sarajevo
}

\begin{abstract}
This article discusses a famous agreement between King Alfonso V of Aragon and Naples and the Grand Duke of Bosnia, Stjepan Vukčić Kosača signed on 19 February 1444 , as a result of both political and millitary circumstances that had brought, in that particular moment, the local interests of one Bosnian lord and the foreign policy plans and ambitions of the most powerful Mediterranean ruler to the same level. It also offers a new interpretation of this treaty in terms of its practical application, as well as its re-reading and translation, based on a high-resolution facsimile.
\end{abstract}

Key words: agreement, treaty, Alfonso V of Aragon, Stjepan Vukčić Kosača, 1444, vassal, senior.

In the fall of 1443, the Grand Duke of Bosnia, later Herzog of Saint Sava, Stjepan Vukčić Kosača (1435-1466) was in hostile relations with almost all of his neighbours. In spite of the political and economic power he had inherited and managed to preserve well after the death of his uncle Sandalj Hranić, duke Stjepan failed to significantly influence the selection of the new candidate to the Bosnian throne, which had remained vacant following the death of King Tvrtko II (1420-1443). An opposing position towards the new ruler, Stefan Tomaš (1443-1461) had soon led to the outbreak of war. ${ }^{1}$ In the conflicts that followed, Stjepan Vukčić, apart from the King of Bosnia, also faced duke Ivaniš Pavlović, duke Petar Vojsalić, as well as the nobility from the Land of Hum, the Semković and Jurjević families. However, the most severe

\footnotetext{
·MA, History Department. Email address: almir.peco@ff.unsa.ba

${ }^{1}$ For more on the subject, see: Ćošković 1988, 27-36.
} 
opponent was Venice whom he had fought in the Zeta area. $\mathrm{W}^{2}$ aging a two-front war had brought the Duke of Bosnia into a very difficult situation, hence, in 1444, both sides suffered severe losses in territory. Armies of the King of Bosnia and Ivaniš Pavlović, aided by Jurjević nobility, managed to take the lucrative customs town Drijeva, which then fell into the king's hands. ${ }^{3}$ That was a significant military, political, and, above all, economic blow to Stjepan. The war with Venice was not unfolding any better either. It had become clear that things were getting out of control in late January 1444, when Duke Stjepan lost Omiš and the Poljica župa to Venice. ${ }^{4}$ In the context of those wars, the fact that the Bosnian lord was deprived of the services of the Ottoman army was decisive, since it was their support and assistance he would frequently use in dealing with his opponents. ${ }^{5}$ Also, the Ottomans were in a difficult situation at the time, since they were involved in a war with a broader Christian coalition that comprised of joint military forces led by the Hungarian king Wladyslaw, Janos Hunyadi and the Serbian despot Đurađ Branković. ${ }^{6}$ These circumstances, in which a more significant Ottoman involvement into the internal Bosnian issues was limited and, at the same time, the hope that the pending victory of the Christian army would soon end the Ottoman presence in Europe, intensified Stjepan Vukčićs's diplomatic activities and his quest for a strong ally and protector. Keeping in mind that the Bosnian duke did not have a good relationship with the Hungarian king either, he asked for help from one of the most powerful European ruler at the time, Alfonso V king of Aragon (1416-1458) who managed to obtain the crown of Naples in 1442 . He assumed the Neapolitan throne in 1442, and not only had he had the military resources that Stjepan Vukčić could count on, but he also enjoyed a global political authority which he could use on Vukčićs behalf. ${ }^{7}$

On the other hand, Alfonso's expansionist ambitions were not satisfied with the conquest of Naples. By promoting himself as the protector of Christianity and the leader in the fight against the infidels, he turned his expansionist policy towards the east. During 1442 and 1443, the Ottoman army suffered a series of defeats by the Christian coalition in Transylvania, in the lower Danube region and in Bulgaria, which additionally increased optimism and hope that the Ottomans would soon be defeated. ${ }^{8}$ As King of Naples, Alfonso V showed primary interest in the Mediterranean and the area of the Balkans, where he had been traditionally

${ }^{2}$ Ћирковић 1964a, 72; Ćošković 1988, 39, 45.

${ }^{3}$ Тошић 1987, 148-149.

${ }^{4}$ Ћирковић 1964а, 73; Ћирковић 1964b, 277.

${ }^{5}$ Filipović 2019, 323-326, 331, 346-347.

${ }^{6}$ Острогорски 1959, 523; Ћирковић 1964а, 72; Ryder 1990, 302.

${ }^{7}$ For detailed information on Alfonso of Aragon see: Ryder, 1976; Ryder 1990.

${ }^{8}$ Ryder 1990, 302. 
competing with the Republic of Venice. In that sense, the new situation in which a certain Ottoman defeat was expected, Alfonso V saw an opportunity to engage more actively in the Balkans. He was motivated in his intention by both the antiOttoman fight, as well as an opportunity to harm the Venetian interests and terminate their dominance in the area. ${ }^{9}$ It should be emphasised that the central goal of Alfonso's eastern politics was pushing the Ottomans out of Europe, but he also had Constantinople high on his priority list, since he had dreamed of the imperial crown and dignity. ${ }^{10} \mathrm{He}$ attempted to implement his plans through connecting and establishing close relations with the local Balkan lords, hence, it is possible to understand his more intensive correspondence with the Duke of Bosnia. ${ }^{11}$ Apart from that, establishing connections with Stjepan Vukčić meant that Alfonso could benefit on the other side as well. By conquering Naples in 1442, he had inherited from his predecessors also the claims to the title of the King of Hungary, which was a continuation of the traditional aspirations of the Neapolitan kings towards Hungary. He had tried to turn that nominal situation into reality, hence he emphasised, in favourable moments, his interest into the Holy Crown of Hungary. In his intent to reach Hungary, the Neapolitan king saw Bosnia as the main transit route. In that sense, he saw the connection with Stjepan Vukčić as highly beneficial. ${ }^{12}$

In almost all aforementioned spheres of activity, there was a common interest between Duke Stjepan and king Alfonso, which created a precondition for establishing closer cooperation. Their previous acquaintanceship and the established diplomatic contacts that had existed prior to 1442, intensified in the period when the Duke of Bosnia, pressured by both domestic and foreign factors, found himself in a rather difficult situation. ${ }^{13}$ In the midst of war, in January 1444, Stjepan Vukčić sent two emissaries to the Neapolitan court: dukes Juraj and Pavle, who sought help from Alfonso V. ${ }^{14}$ Upon his request, the Neapolitan king agreed to advocate with

\footnotetext{
${ }^{9}$ King Alfonso's anti-Ottoman politics has for a long time been a subject of discussions in historiography. He was often objected because of indecisiveness and a lack of concrete actions in the period of the Crusades. For more recent views on this matter with a comprehensive presentation of the previous historiographic positions, see: Aloisio 2017,64-72.

${ }^{10}$ Острогорски 1959, 526.

${ }^{11}$ Such a strategy was familiar to the Neapolitan king, since he was known to have established contacts and befriended the rulers of Egypt, Syria and Ethiopia. Ryder 1976, 39; Спремић 1974, 455-469; Спремић 1985, 128.

${ }^{12}$ Спремић 1985, 129.

13 Ћирковић 1964а, 74-75.

${ }^{14}$ Спремић 1974, 455-456. Ante Babić argue the possibility that it was Juraj Čemerović. Babić claims the possibility that it was Juraj Čemerović, a duke and an honorary knight and diplomat at the court of Duke Stjepan Vukčić, while Tošić argue it was Đurad Stjepković. The other emissary was Pavle Marković, a duke, voivode, knight and Herzog Stjepan Vukčić Kosača’s, and, later, Duke Vladislav Kosača’s man. Babić 1960, 59; Тошић 2002, 68-69.
} 
the Emperor of the Holy Roman Empire, Venice and the King of Bosnia the return of the lands seized from the Duke. The negotiations were successful and sealed by the treaty of 19 February 1444, by which Duke Stjepan Vukčić Kosača nominally became a vassal of Alfonso V of Aragon. ${ }^{15}$

The treaty was comprised in accordance with Stjepan Vukčićs proposal, presented to Alfonso $\mathrm{V}$ by his emissaries. It is possible that the Neapolitan king changed and amended certain items of the treaty by inserting some of his demands to which Stjepan finally agreed. The gravity of the obligations that Duke Stjepan accepted becoming indebted to King Alfonso leads into thinking that the conditions under which the Duke of Bosnia had become a vassal to the Neapolitan king were not favourable but acceptable, keeping in mind the dire circumstances and the background of the very agreement. The charter which after ten years confirmed/ re- established the vassal relationship between Herzog Stjepan and King Alfonso $\mathrm{V}$ can be used for comparison. Although the charter was essentially the same to the 1444 treaty, the content of the 1454 charter reveals some rather relaxed obligations of Herzog Stjepan towards the Neapolitan king. ${ }^{16}$

\section{Content of the Charter}

By the February 1444 charter, Duke Stjepan Vukčić Kosača "wilfully with all his vassals" submitted to King Alfonso V of Aragon. On the principles of the faithful servility and the noble faith, the king entrusted the "faith", i.e. promised the Duke, his children, as well as his soldiers personal and safety of the property on the king's territory, guaranteeing that no "novelty, accident, injustice, evil or damage" would befall him. The treaty did not entail an oath to be taken, which might have been the feudal practice in medieval Bosnia. ${ }^{17}$ In case the Duke or someone from his land faced a wrongdoing of any kind, the Neapolitan king promised, quite equivocatingly, that

15 Thallóczy 1914, 356-357; Ћирковић 1964a, 75.

${ }^{16}$ Here we will not go into details of the 1454 charter. For more on the subject, see: Thallóczy 1914, 394-400; Ћирковић 1964a, 213. Historiography has so far primarily emphasised the need of Duke Stjepan for a strong ally and protector he had found in Alfonso V. However, it should be kept in mind that the Neapolitan king had his interests, especially if we observe such treaties through a prism of his wider politics. It is interesting that both the treaties between Herzog Stjepan and Alfonso $\mathrm{V}$ took place during intensive preparations and increased activities of the Neapolitan king for the Christian confrontation with the Ottomans. Relying on the Balkan lords who had been willing to fight or who were already actively involved in the war against the sultan's army reflects his conceived strategy in an attempt to realise his highly positioned political and military goals. The treaties with the Duke of Bosnia are no exception in relation to other similar treaties between the Neapolitan king and other Balkan dignitaries, for example with Demetrios Palaiologos, the despot of the Morea (1451), or Skenderbeg (1451). Спремић 1974, 458-466; Aloisio 2017, 6869; Premović 2019, 94-99.

17 Ћирковић 1962, 321-322. 
he would provide "assistance and service that is at the disposal" in order to protect and defend him the same way "he would protect his own country". The charter further reads that the king accepts Stjepan for his loyal servant and friend, and the Duke accepts the king as his protector, surrendering to him with his fortresses, lands and župe, all mentioned by name, including the areas he considered his own, but which he had lost in the ongoing war. ${ }^{18}$

Furthermore, the charter reads that the Duke of Bosnia obliged himself to the king that he would provide for the salary for each year the king spent in the war, as well as the money for a thousand horsemen, and that he would immediately pay 32,004 ducats for the current year. ${ }^{19}$ On the other hand, in the time of peace, the Duke would also pay a contribution that he had up to then paid to the Ottoman sultan. Also, upon the request of the Neapolitan king, the Duke was obliged to terminate any war until the king decided otherwise. Finally, those who obstructed the provisions of the treaty would face a rather high sanction - a 10,000 ducats fine.

In accordance with the past interpretations, the treaty between Alfonso $\mathrm{V}$ of Aragon and Stjepan Vukčić Kosača remained a dead letter. Neither side followed the provisions for a longer period of time. Still, it may have been that the implementation depended on the general political situation, mostly the success of the Christian coalition in the war against the Ottomans. Although nowhere explicitly stated, it appears that both sides tacitly approved that, since the true implementation of the treaty was only possible in the conditions where Stjepan Vukčić was exempted from the authority of the Ottoman sultan. We could observe this treaty in that context also as Stjepan's attempt of a sort to ensure and find an alternative solution if such a state became a reality. Still, we should not entirely reject such a possibility, at least for the period immediately after the treaty had been signed. It is not entirely clear why Stjepan would enter any form of a negotiating process at all, or sign a treaty with the Neapolitan king, if he had no intention of implementing it, or if he had no immediate use or assistance form the treaty that would help him in wars he was involved in and because of which he had turned to the Neapolitan king in the first place, asking for protection. What is more, a special article in the treaty provides for the immediate payment by Stjepan to Alfonso V of the aforementioned sum for a thousand horsemen.

It is difficult to determine the extent to which the Neapolitan king influenced the solving of Stjepan's war troubles, but it is certain that the very call for his supreme authority had to have had a certain influence and a political significance. The concrete

${ }^{18}$ The example of Omiš and Poljice.

${ }^{19}$ Accordingly, the monthly salary for 100 horsemen would be 8000 ducats, which is 96000 ducats annually. Thus, it remains unclear why was Stjepan obliged to pay "only" 32000 ducats for the current year, which is the quarter of the salary for 1000 soldiers. 
help that was beyond the diplomatic framework can be seen in the data from April 1445. Then, King Alfonso sent to his ally four galleons that anchored in the town of Novi, most probably against the Venetian lands in Zeta and Dalmatia. That caused a justifiable concern and disturbed the neighbouring population, especially because the backup and additional ships had been expected..$^{20}$ Still, all remained a threat and no action was taken most probably because, at the time, Duke Stjepan started peace negotiations with the Venetian Republic, which ended successfully in August that same year. The following year, Stjepan made peace with Bosnian king Tomaš, making his position more favourable. ${ }^{21}$ At the same time, the anti-Ottoman coalition failed and the Ottomans again established a strong position in the Balkans. In such circumstances, the connection between Alfonso V and Stjepan Vukčić was not terminated but, understandably, the signed treaty could no longer have been implemented.22 That certainly did not jeopardise their friendly relations from which Stjepan Vukčić benefitted economically to a certain extent, since it is known that he had distributed wool from the Aragon lands to Novi, and that he supplied himself with wheat and salt from southern Italy. ${ }^{23}$ Cordial and friendly relations are best confirmed by mutual readiness and determination to re-establish them ten years later. It is interesting that it occurred in the time of strong preparations of an antiOttoman campaign after the recent fall of Constantinople which restored faith that the Ottomans would after all be pushed away from the Balkans. As expected, one of the main protagonists in the planning was Alfonso V of Aragon.

20 "Ad primum videlicet: serenissimo principe et excellentissima signoria vostri fidelissimi servidori exponemo ala vostra serenita, chomo de I ano passado siando vizeconte misser Marin Contarini vescovo de Cataro ali do avril de I ano passado vene galie quatro de Cathelani in el colfo de Cataro, et achostosse a chastel de Novi del conte Stefano voevoda de Bosna in quela nimigo de la detta signoria, e fo vose per tuta Dalmazia, che drio quele quatro galie vegniva vinti galie de Catellani, la qual vose messe terror a tuta Dalmatia e specialmente a Cataro...”. Ljubić 1890, 250; Ћирковић 1964a, 89; Marinescu 1994, 111.

${ }^{21}$ Ćošković 1988, 76, 89-91.

${ }^{22}$ So far, it has been emphasised that King Alfonso had objected to Duke Stjepan the nonfulfillment of the obligations arising from the treaty. Such a conclusion was based on the document from 1466, where the Neapolitan king answered to Stjepan's demand for help in fight against the enemy: "Rex Aragonum etc. Illustris et magnifice Dux amice noster carissime...In primis ad illud quod a nobis requeritis auxilium et opem nostram ad propulsandos inimicos vestros et magnificientiam vestram ab omni hostium injuria illesam servandam, promptissimum futurum nos pollicemur, si econverso ea ab illustri magnificentia vestra nobis servabuntur, que inter nos conventa et pacta extiterunt..." Thallóczy 1914, 870. The content of the document does not necessarily imply any acrimony of the king towards Duke Stjepan for not fulfilling the obligations. The answer of Alfonso V reveals conditions under which Stjepan would be granted the assistance he sought, and they rest in the implementation of the treaty which, in the circumstances of the strong Ottoman presence, was almost impossible. The document, written in a moderate, cordial and amicable tone, does not leave the impression of displeasure with his previous behaviour. Cf. Ћирковић 1964a, 76.

${ }^{23}$ Ћирковић 1964а, 77-78; Спремић 1971, 23-24. 
On the other hand, in the attempt to seize the Hungarian throne, Alfonso V undertook certain measures in early 1466. He then sent his fleet to Stjepan's town of Novi, with the purpose of reaching Hungary through Drijeva. ${ }^{24}$ The attempt was unsuccessful but it shows his clear intention to use the relations he had with the Duke of Bosnia. Still, he could not count on some more serious attempts. Although obliged by the treaty, Stjepan did not partake in the war the Neapolitan king waged against Venetians (1449-1450). The passivity the Duke displayed at the time and non-compliance with the obligations arising from the treaty negatively reflected their mutual relations, hence they signed a similar treaty in 1454 . That additionally confirms that the implementation of the 1444 treaty had not been possible, keeping in mind the circumstances of the time.

\section{The Charter}

The charter was first published by Lajos Thallóczy, in $1914 .{ }^{25}$ Keeping in mind that a facsimile of the charter was not published then, more than six decades would pass before the transcript could be examined. Then, on two occasions, Marko Vego published the images of the original document. Vego presented the first facsimile in a paper he published in $1978,{ }^{26}$ but, because of the small format and poor resolution, this image has almost no utilitarian value for researchers. In the second, partly corrected version of the same paper that was published two years later, ${ }^{27}$ the image of the charter was in a bigger format and an improved resolution, but still under the level that would meet the necessary standards. Vego to an extent amended and changed Thallóczy's rather correct reading, but, in doing so, he himself made several minor omissions and wrongly read certain words. Together with the transcription, Vego published a quite satisfactory translation of the charter, which had nevertheless remained incomplete in certain places, or unclear.

The charter was written in Latin and Italian, on the basis of the Cyrillic template that Stjepan Vukčić's emissaries brought. The exceptional value of the charter is the abundance of topographic data which are especially important for the study of the Kosača family estates. ${ }^{28}$ The document is today preserved in the General Archive of the Crown of Aragon in Barcelona. Sadly, we did not manage to gain a direct insight into the charter, which is why we are unable to analyse the external characteristics of

\footnotetext{
${ }^{24}$ Ћирковић 1964а, 91; Спремић 1985, 130.

25 Thallóczy 1914, 360-363.

${ }^{26}$ Vego $1978,123-142$.

${ }^{27}$ Vego 1980, 452-486.

${ }^{28} \mathrm{On}$ the basis of these information and indications, Mihailo Dinić wrote his pivotal study in historic topography that was the starting point for research of the localities mentioned in the charter. See: Аинић 1940, 151-257. The same paper in: Аинић 1978, 178-270.
} 
the document (dimensions, materials, ink). In this paper, we present the new, quality images of the original document, together with the transcript and the translation. ${ }^{29}$

\section{Text of the Charter ${ }^{30}$}

Pro duce Bossine.

Alfonsus etct [et cetera] uniuersis ${ }^{31}$ et singulis huiusmodi ${ }^{32}$ nostras litteras inspecturis presentibus et futuris gratiam nostram et bonam voluntatem. Ut honor qui operante altissimo ex deditione illustris Sthefani ducis Bossine, qui sponte sua cum vasallis ${ }^{33}$ suis omnibus sese nobis dedidit ${ }^{34}$ reliquis Mt $[\text { Maestatis }]^{35}$ nostre honoribus inpresentiarum ${ }^{36}$ est accumulatus, omnibus innotescat et alias etiam ut officiales, subditi et stipendiarii nostri tenaciter obseruent ea que per nostram Celsitudinem ipsi illustri duci promissa fuerunt capitula que inter nos et ipsum

.I. [illustrem] ducem seu verius per magnificos viros comitem Georgium et comitem Paulum nuncios et legatos ac assertos sindicos suos eius nomine inita celebrata et firmata extiterunt capitula ipsa presentibus inseri iussimus serie subsequenti:

Capituli pacti et conuentioni facti, firmati et iurati ${ }^{37}$ tra la Serenissima Mta. $[\text { Maesta }]^{38}$ delo ${ }^{39}$ segnore ${ }^{40}$ Re de Aragona ${ }^{41}$ et de Sicilia citra et ultra farum et cetera della una parte et li spectabili et magnifici conte Georgio et conte Paulo oraturi ${ }^{42}$

${ }^{29}$ We hereby express sincere gratitude to prof. dr. Hrvoje Gračanin, Chair of the doctoral studies in Pre-modern history at the Faculty of Philosophy, University of Zagreb, who kindly provided and placed the images at our disposal.

${ }^{30}$ We present the text of the charter in its entirety, the way it was written with abbreviations, with the added punctuation where we thought appropriate. The square brackets contain solutions to the abbreviations. Tallóczy's version contains some interpretations of abbreviations, while Marko Vego's version does not contain any abbreviations.

${ }^{31}$ Due to the originality of the transcription, we will not transcribe the letter $\mathrm{u}$ in the middle of the word preceding a vowel as the letter v, unlike Thallóczy and Vego. We will not mark these differences except in the names of župa and fortresses.

${ }^{32}$ Vego: huismodi

${ }^{33}$ Vego: vassalis

${ }^{34}$ Vego: dedit

35 Thallóczy: majestatis

${ }^{36}$ Thallóczy and Vego: in presentiarum

${ }^{37}$ Thallóczy and Vego: jurati

${ }^{38}$ Vego's version: Maestra

39 Thallóczy: de lo

${ }^{40}$ Thallóczy: signore

${ }^{41}$ Vego: Aragonia

${ }^{42}$ Thallóczy and Vego: oratori 
ambassiatori et asserti sindici delo .I. [illustro] Sthefano ${ }^{43}$ ducha de ${ }^{44}$ Bossina in nome et per parte de isso prefato.I. [illustro] ducha dela ${ }^{45}$ parte altra.

In primis $^{46}$ la prefata Mta. [Maesta] ${ }^{47}$ e contenta et promete de affidare et assecurare et damo affida et assecura la persona del prefato .I. [illustro] ducha et soi figlioli, so exercito, auro, argento, ioye ${ }^{48}$ et qualuncha altre cose soe che per tempo verranno in seruicio dessa Mta. [Maesta]. ${ }^{49}$ Ita videlicet, che tanto venendo et stando inli $^{50}$ seruicii de essa Mta. [Maesta] quanto partendosse ${ }^{51}$ et tornando nele terre desso prefato .I. [illustro] ducha tante volte quante aloro sera ben visto ${ }^{52}$ siano liberi, securi, guidati et affidati et non li sia fata ${ }^{53}$ nouitate, molestia, iniuria ${ }^{54}$ dampno oy male inpersona ${ }^{55}$ ney roba sua oy loro ante siano tractati como veri et boni seruitori recomandati ${ }^{56}$ et amici dessa Maiesta ${ }^{57}$

Item promete la prefata Mta. [Maesta] alo prefato .I. [illustro] ducha che in $\mathrm{casu}^{58}$ che aluy o a alcune dele terre soe se mouesse oy se fecesse nouitate alcuna per qualuncha ri, principi ${ }^{59}$, duchi oy conti oy per qualuncha comunita oy segnoria essa $S$ [Serenissima] ${ }^{60}$ Mta. [Maesta] prestata ${ }^{61}$ alo prefato .I. [illustro] ducha ogni ayuto $^{62}$, subsidio oi ${ }^{63}$ fauore $^{64}$ che le sera possibile et lo deffendera deli predicti

\footnotetext{
${ }^{43}$ Vego: Stihfano

${ }^{44}$ Thallóczy: di

45 Thallóczy: de la

46 Thallóczy: Imprimis

${ }^{47}$ Vego: Maestra

48 Thallóczy: joye

${ }^{49}$ Vego: Maestra

50 Thallóczy and Vego: in li

${ }^{51}$ Thallóczy: partendose

52 Thallóczy: uisto

53 Thallóczy: fatta

${ }^{4}$ Thallóczy: injuria

${ }^{55}$ Thallóczy and Vego: in persona

${ }^{56}$ Thallóczy: recommandati

${ }^{57}$ Vego: Maesta

${ }^{58}$ Vego: caso

59 Thallóczy: principe

${ }^{60}$ Thallóczy: I.; Vego: ilustrissima

${ }^{61}$ Thallóczy and Vego: prefata

${ }^{62}$ Vego: aijuto

${ }^{63}$ Thallóczy: oy

${ }^{64}$ Thallóczy and Vego: favore
} 
quanto ${ }^{65}$ bona mente porra non altra mente ${ }^{66}$ che deffenderia lo proprio statu dessa Mta. [Maesta] et damo essa Mta. [Maesta] piglia et accepta lo prefato .I. [illustro] ${ }^{67}$ ducha per suo vero et bono recomandato ${ }^{68}$ seruitore et amico. Et viceuersa lo prefato .I. [illustro] ducha damo piglia et accepta la prefata Mta. [Maesta] ${ }^{69}$ per suo vero et bono protectore, maiore et deffensore et se rende ala soa Maesta con $\mathrm{li}^{70}$ castelli, terre et contati infrascripti, videlicet:

Sochol con un contato che se chiama Drina, Toyeuacts $^{71}$ Vdrinagliano ${ }^{72}$ castello conlo ${ }^{73}$ contato, Vatraro ${ }^{74}$ Sutisci ${ }^{75}$ castello conlo ${ }^{76}$ contato, Nouio ${ }^{77}$ Gorasdo castello conlo $^{78}$ contato, Samobor Obribudo castello conlo ${ }^{79}$ contato, Chechnauchoy castello conlo ${ }^{80}$ contato, Mileseuischi ${ }^{81}$ castelloconlo ${ }^{82}$ contato, Consina conlo ${ }^{83}$ chesegnoriano li Turchi dela ${ }^{84}$ Grecia dove sta un Sancto che fa grandi miraculi ${ }^{85}$, Cosisti castello con$10^{86}$ contato, Cochangu ${ }^{87}$ in Brisiniza ${ }^{88}$ castello $^{89}$ conlo $^{90}$ contato, Creseuaz Opolinio ${ }^{91}$

\footnotetext{
${ }^{65}$ Thallóczy: quando

${ }^{66}$ Thallóczy and Vego: altramente

${ }^{67}$ Thallóczy: Ilmo

${ }^{68}$ Thallóczy: recommendato

${ }^{69}$ Vego: Maestra

${ }^{70}$ Thallóczy: conli

${ }^{71}$ Thallóczy: toyeuacs,Vego: Toyevacts

${ }^{72}$ Thallóczy: Vdrynagliano, Vego: Vdrinagliauo

${ }^{73}$ Thallóczy: con lo

${ }^{74}$ Thallóczy: Vatrato

75 Thallóczy: Sucisti, Vego's version: Sutisti

${ }^{76}$ Thallóczy: con lo

77 Thallóczy and Vego: Nonio

${ }^{78}$ Thallóczy: con lo

79 Thallóczy: con lo

${ }^{80}$ Thallóczy: con lo

${ }^{81}$ Vego: Mile Sevischi

${ }^{82}$ Thallóczy: con lo

${ }^{83}$ Thallóczy: con lo

${ }^{84}$ Thallóczy: de la

${ }^{85}$ Thallóczy: miracoli

${ }^{86}$ Thallóczy: con lo

${ }^{87}$ Vego: Cochangn

${ }^{88}$ Vego: Brisniza

${ }^{89}$ Vego: castelo

90 Thallóczy: con lo

${ }^{91}$ Vego: Opolimio 
castello conlo ${ }^{92}$ contato, Ostrauiza ${ }^{93}$ Vbistrizi castello conlo ${ }^{94}$ contato, Osip castello

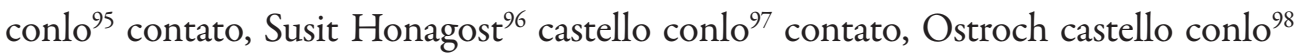
contato ali confini ${ }^{99}$ de Albania, Noui ${ }^{100}$ Vpiuii ${ }^{101}$ castello conlo ${ }^{102}$ contato, Colobrich Verramu ${ }^{103}$ castello conlo ${ }^{104}$ contato, Biseuatts Vtrebign ${ }^{105}$ castello conlo ${ }^{106}$ contato, Novi Vdrazanich ${ }^{107}$ castello conlo ${ }^{108}$ contato ala ${ }^{109}$ marina vicino de Ragusa la via de Albania, Rixan ${ }^{110}$ appresso de Cataro ala ${ }^{111}$ marina castello conlo ${ }^{112}$ contato sta la via de Albania appresso della dita terra de Cataro, Vnizacs ${ }^{113}$ Vniuesegno ${ }^{114}$ castello e contato, Vidosich Vuidouopoglyo ${ }^{115}$ castello conlo ${ }^{116}$ contato, Popohosti Vpopohu castello con contato, Iblayascum som sem glyom ${ }^{117}$ castello con contato, Posichell Vdobrauah $^{118}$ castello conlo ${ }^{119}$ contato, Neboysa Vnitericih ${ }^{120}$ castello conlo ${ }^{121}$ contato,

92 Thallóczy: con lo

${ }^{93}$ Thallóczy and Vego Ostraviza

${ }^{94}$ Thallóczy: con lo

${ }^{95}$ Thallóczy: con lo

${ }^{96}$ Thallóczy: honagust

${ }^{97}$ Thallóczy: con lo

${ }^{98}$ Thallóczy: con lo

${ }^{99}$ Vego: confinii

${ }^{100}$ Thallóczy and Vego: Novi

${ }^{101}$ Thallóczy: vpini

${ }^{102}$ Thallóczy: con lo

${ }^{103}$ Vego: Verramii

${ }^{104}$ Thallóczy: con lo

105 Thallóczy and Vego: V(v)tribigno

${ }^{106}$ Thallóczy: con lo

${ }^{107}$ Vego: vdrazavich

${ }^{108}$ Thallóczy: con lo

109 Thallóczy: a la

110 Thallóczy and Vego: Rixano

111 Thallóczy: a la

112 Thallóczy: con lo

113 Thallóczy: Vnizats

${ }^{114}$ Thallóczy: uniuesegno, Vego's version: Vnivesegno

115 Thallóczy: Viudonopoglyo, Vego's version: Vvidovopogliio

116 Thallóczy: con lo, Vego's version: con

${ }^{117}$ Thallóczy: Iblagayscu', sem som glyom, Vego's version: Iblagay scu' Som som glyom.

${ }^{118}$ Thallóczy: Vdobranah, Vego's version: Vdobravah

119 Thallóczy: con lo

${ }^{120}$ Vego: Vinteritch

${ }^{121}$ Thallóczy: con lo 
Vratar castello conlo ${ }^{122}$ contato et ha una gran ${ }^{123}$ gabella de sale, Vergolaz Vgor cohi ${ }^{124}$ supi castelo con contato, Cimiacho Vbrechinich castello conlo ${ }^{125}$ contato, Visuch Vtusirich castello con contato, Onis castello con $10^{126}$ contato ala ${ }^{127}$ marina Indalmacia $^{128}$, Polis un gran contato sensa castello, Prolosats ${ }^{129}$ Vposutro castello con lo contato, Rogu Vdumpno castello conlo ${ }^{130}$ contato, Imozchi Huimoth ${ }^{131}$ castello et contato, Crezeuacts ${ }^{132}$ Vbelach castello con contato, Radobiglia un contato senza castello, Nouo ${ }^{133}$ Vluzi castello con contato, Hunereti ${ }^{134}$ Biogrado castello con contato, Vrabaz en Eretia ${ }^{135}$ castello con contato, Borauaz en Erettua ${ }^{136}$ castello con contato, Bioschi Vbiloy castello et ${ }^{137}$ contato, Chom ${ }^{138}$ Vdrabez $^{139}$ castello et ${ }^{140}$ contato, Veletin Vsagorie castello con contato, Hioball ${ }^{141}$ Vsagorie castello con contato, Hihelech Vgobici castello et ${ }^{142}$ contato, Codidich Sunrech buzanio castello et ${ }^{143}$ contato, Sustich Vsopio castello et contato, Ravansche ${ }^{144}$ Vbrisino castello con contato, Seravansche castello conlo ${ }^{145}$ contato, Medun castello et ${ }^{146}$ contato, Socho castello et contato.

Item offere et promete lo prefato .I. [illustro] ducha de pagare realiter et de facto ala prefata Mta. [Maesta] essendo essa Mta. [Maesta] en guerra lo stipendio

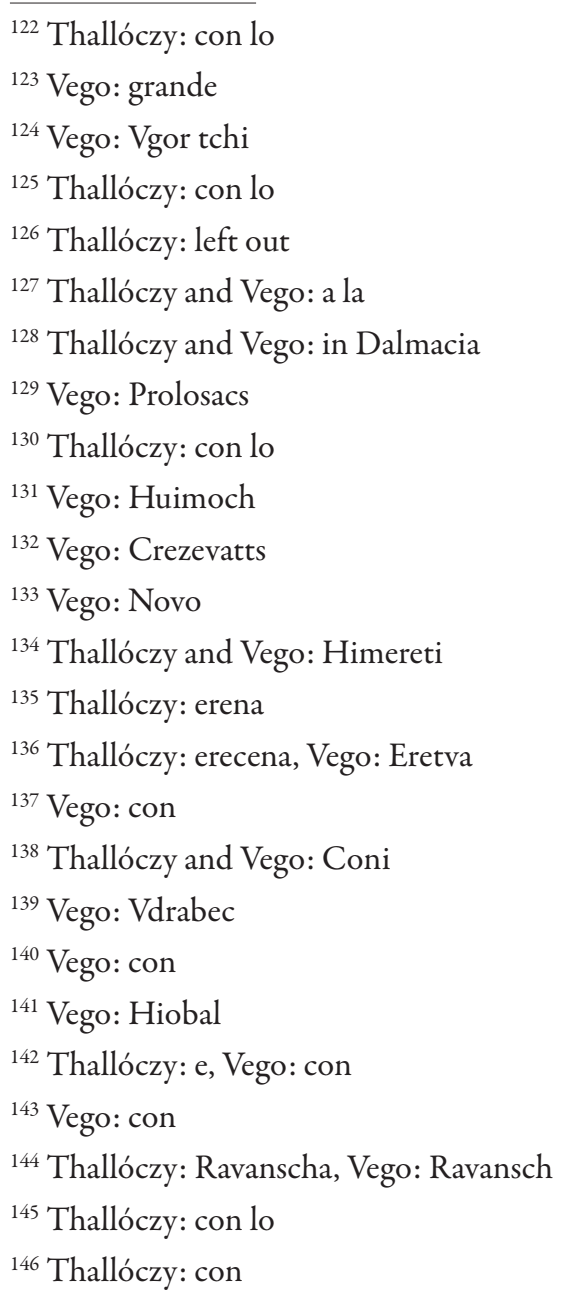


et soldo de mille caualli ala usanza ytaliana ${ }^{147}$ secundo li $^{148}$ paga essa Mta. [Maesta] cio $\mathrm{e}^{149}$ arasone $\mathrm{e}^{150}$ de octo ducati per lança lo mese in quisto ${ }^{151}$ modo che isso prefato .I. [illustro] ducha mandara incontinenti per lo soldo delo presente anno ducati XXXII milia e quatro que monta lo soldo deli diti mille caualli et cussi ogni anno durante la dicta querra lo quale termino incomençe ${ }^{152}$ acurrere $^{153}$ del di dela ferma deli presenti ${ }^{154}$ capituli innante ${ }^{155}$ passata impero et finita la dita guerra et stando essa Mta [Maesta] in pace, promete lo prefato ${ }^{156}$.I. [illustro] ducha pagare ogni annno ala prefata Mta. [Maesta] lo tributo che intempo ${ }^{157}$ passato pagaua et era solito mandare et pagare alo gran Turcho.

Item offere et promete lo prefato.I. [illustro] ducha ala prefata $S$ [Serenissima] ${ }^{158}$ $\mathrm{M}^{\text {ta }}$ [Maesta] defare ${ }^{159}$ rumpere guerra ale spese de isso $^{160}$ illustro $^{161}$ ducha con ${ }^{162}$ qualuncha ri, principi, duchi oy conti oi qualuncha comunita oi ${ }^{163}$ segnoria ad ogni peticione, requisicione et instancia dela ${ }^{164}$ prefata $\mathrm{M}^{\text {ta }}$. [Maesta] et quella prosequire ${ }^{165}$ fin $^{166}$ che per la prefata $M^{\text {ta }}$. [Maesta] altramente fosse deliberato et ordenato $^{167}$.

Item prometeno et se obligano medio iuramento ${ }^{168}$ li spettabili et magnifici conte Georgio et conte Paulo pero che loro non portano suficiente potesta per concludere

\footnotetext{
147 Thallóczy: italiana

${ }^{148}$ Vego: la

${ }^{149}$ Vego: cioie

${ }^{150}$ Thallóczy: a rasone

${ }^{151}$ Vego: questo

${ }^{152}$ Vego: incomenece

${ }^{153}$ Vego: assicurare

${ }^{154}$ Thallóczy: presente

155 Thallóczy and Vego: in innante

${ }^{156}$ Vego: profato

157 Thallóczy and Vego: in tempo

${ }^{158}$ Thallóczy and Vego: left out

159 Thallóczy and Vego: de fare

${ }^{160}$ Thallóczy: illo, kod Vega: iso

${ }^{161}$ Thallóczy: left out

${ }^{162}$ Thallóczy: contra

${ }^{163}$ Thallóczy: o

${ }^{164}$ Thallóczy: de la

${ }^{165}$ Vego: prossequire

166 Thallóczy and Vego: fino

${ }^{167}$ Vego: ordinato

168 Thallóczy: juramento
} 
li presenti capituli che fra tre misi partuti daqua ${ }^{169}$ mandarano ${ }^{170} \mathrm{li}^{171}$ consimili capituli signati de propria manu delo ${ }^{172}$ prefato .I. [illustro] ducha et sigillati de so sigillo et che la prefata $\mathrm{M}^{\text {ta }}$. [Maesta] non sia tenuta ne obligata alo prefato .I. [illustro] ducha fin tanto che li diti capituli siano assignati in potere de essa Maesta.

Datum in castro Nouo ciuitatis nostre Neapolis die XVIII mensis febroarii ${ }^{173}$ VII indictionis anno a natiuitate Domini MCCCCXXXXIIII. Rex Alfonsus.

Dominus rex mandauit mihi Francisco Martorell. Mandamus propterea per has easdem de certa nostra scientia et expresse uniuersis et singulis officialibus subditis et stipendiariis nostris maioribus et minoribus quocunque nomine censeantur eorumque locatis ${ }^{174}$ presentibus et futuris. Quatenus preinserta capitula et omina ac singula in eis contenta teneant firmiter et obseruent tenerique et obseruari faciant inuiolabiliter per quoscunque iuxta ${ }^{175}$ sui seriem pleniorem et non contraueniant quauis causa si gratiam nostram caram habent iramque et indignationem nostram ac penam decem milium ducatorum nostro erario applicandorum cupiunt euitare. In cuius rei testimonium presentes fieri iussimus sigillo nostro communi Aragonum in ${ }^{176}$ pendenti munitas. Datum in castro Nouo ciuitatis nostre Neapolis, die XVIIII, mensis febroarii ${ }^{177}$, VII indictionis, anno a natiuitate Domini MCCCCXXXXIIII regni huius Sicilie citra farum decimo aliorum vero regnorum nostrorum, anno XXVIIII. RexAlfonsus. ${ }^{178}$

\section{Translation}

For the Duke of Bosnia.

Alfonso etc. to all and to individuals who read may our letters in the present and future, our mercy and goodwill. Like the mercy by which the Almighty acts, for the loyalty of the most serene Stephen the Duke of Bosnia, who by his own will and with all his vassals placed himself together with other honours of our highness is now gifted. May it be known to everyone and all else, like our officers, subjects and slaves, that they are to firmly respect that which our highness promised to the

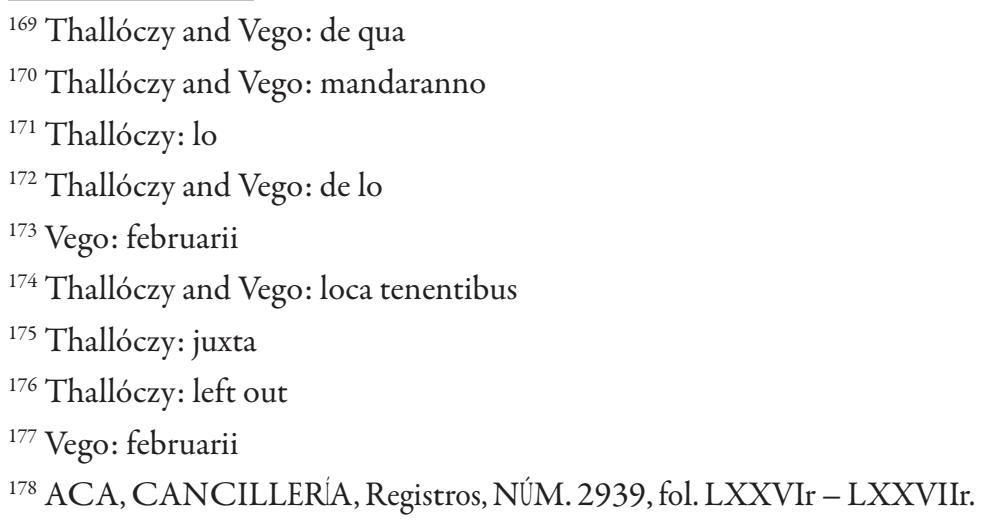


most serene duke, the articles that are between us and the same most serene duke, or more precisely, which were intoduced, proclaimed and confirmed with the eminent counts George and Paul, his emissaries, legates and official representatives, in his name. We have ordered these present conclusions be written as follows:

Conclusions, treaties and concluded agreements that have been confirmed and witnessed between the most serene majesty of King of Aragon and Sicily from both sides of the sea, etc. on the one hand, and the esteemed and majestic count George and count Paul, the messengers, emissaries, and determined trustees of the most serene Stephen, the Duke of Bosnia, on behalf of the same most esteemed duke on the other.

First, said majesty is satisfied and promises to entrust and ensure, and we present the faith and the certainty of character of the most serene duke and his children to his soldiers, gold, silver, valuables and any other of his possessions that will, in time, come into the service of his majesty, that is, both in the arrival and in the departure and the return to the lands of said most serene duke the amount of time as they please to be free, escorted and entrusted, and that no novelty, nuissance, injustice, damage or evil in person in his property or theirs before they are treated as the true, good servants, the recommended friends of his majesty.

Also, said majesty promises to said most serene duke, in case that he or someone from his land should move or do a novelty from any kings, princes, dukes, counts or a municipality or nobility, to provide all assistance, affection and service and to defend him from the said if the mind is right, just as he protects the land of his majesty, and gives his majesty the acceptance and reception to said most serene duke as his faithful and good, recommended servant and friend. On the other hand, as well, said duke extends the reception to said majesty as his faithful and good protector, the more significant and the defender and submits to his majesty with fortresses, lands and župe listed hereunder:

Sokol with a župa named Drina, Tođevac in Drinaljevo fortress with a župa, Vratar in Sutjeska, a fortress with a župa, Novi in Goražde fortress with a župa, Samobor in Pribud fortress with a župa, Klek at Uvac fortress with a župa, fortress Mileševski with the Crna Stjena župa ${ }^{179}$ ruled by Turks from Greece where there is a saint performing miracles, Koznik fortress with a župa, Kukanj fortress in Breznica with a župa, Hrsovac fortress in Polimlje with a župa, Ostrovica fortress in Bistrica with a župa, Osip fortress with a župa, Susid fortress in Onogošte with a župa, Ostrog fortress with a župa at the border with Albania, Novi fortress in Piva with a župa, Klobuk fortress in Vrm with a župa, Mičevac fortress in Trebinje with a župa, Novi fortress in Dračevica with a ž upa at the seaside near Dubrovnik en route to Albania, Risan fortress near Kotor at the seaside with a župa situated en route to Albania near the said land of Kotor,

${ }^{179}$ Аинић 1940, 174. 
Vinačac fortress in Nevesinje with a župa, Vidošić fortress in Vidovo Polje with a župa, Popovski fortress in Popovo Polje with a župa, and Blagaj fortress with the Zachlumia land with a župa, Počitelj fortress in Dubrave with a župa, Nebojša fortress in Večerić with a župa, Vratar fortress with a žmpa where there is a large salt customs, Vrgorac in Gorska Župa, Cimovski fortress in Večerić with a župa, Visuć fortress in Tisurić with a $\check{z} u p a$, Omiš fortress with a župa at the Dalmatian seaside, Poljica, a large county without a fortress, Proložac fortress in Posušje with a župa, Rog fortress in Duvno with a župa, Imotski fortress in Imota with a župa, Kruševac fortress in Blato with a $\check{z} u p a$, Radobilja žzpa without a fortress, Novi in Luka fortress with a župa, Biograd fortress in Neretva with a župa, Borovac fortress in Neretva with a $\check{z} u p a$, Bijela fortress with a $\check{z} u p a$ in Bila, Kom fortress in Dabar with a župa, Veletin fortress in Zagorje with a župa, Obalj fortress in Zagorje with a župa, Jeleč fortress in Gobza with a župa, Hodidjed with Vrhbosna fortress with a župa, Susid fortress in Skopje with župa, Ravanski in Breznica fortress with a župa, Severin fortress with a župa, Medun fortress with a župa, Soko fortress with a župa.

Also, said most esteemed duke offers and promises to pay really and practically every year to said majesty, when his majesty is at war, the salary and money for a thousand horsemen according to the Italian tradition that his majesty is already paying, based on the sum of eight ducats per a horseman a month, so that said most esteemed duke for the current year pays immediately 32,000 and four ducats, the amount that will suffice the payment of said thousand horsemen and provide every year during the said war whose time begins from the firmly determined present conclusions we order in the past and the end of said war when his majesty is in peace said most esteemed duke promises to pay every year to said majesty a contribution that he had paid in the past time and usually sent to the grand Turk.

Also, said most esteemed duke promises to said majesty to end the war at the expense of the same most esteemed duke with anyone, kings, princes, dukes or counts or lordship upon any asking, demand and initiation of said most esteemed majesty and shall continue to do so as long the said majesty decided and ordered otherwise.

Also, the esteemed and majestic counts George and Paul promise and swear under oath that since they did not bring sufficient authorisation to conclude the present articles (conclusions) in three months from now, they would send similar conclusions signed by the own hand of said most esteemed duke, sealed by his seal and that said majesty is not obliged to the most esteemed duke until the said conclusions are made official by the authority of his Highness.

Presented in the fortress Novi of our city of Naples, on 18 February, 7 indiction, year of our Lord 1444. King Alfonso.

His Majesty the King ordered me, Francis Martorelli. That is why we command with this same charter with a clear knowledge and explicitly to all and individually 
to our officers, subjects nd slaves, higher and lower ranking, of any name, recommended also to those at the present and future positions to firmly supervise the previously agreed conclusions and all that they contain and to be upheld and guarded inviolably anywhere fully and that they shall not oppose them regardless of the cause and if they have our dear mercy and want to avoid the wrath and anger and a ten thousand ducat punishment they need to place in our treasury. For the testimony of this present issue we have ordered a confirmation by the common hanging seal of Aragon. Presented in the fortress Novi of our city of Naples, on 19 February, seventh indiction, Year of Our Lord 1444. Tenth year of our rule over this Kingdom of Sicily, on this side of the Sea, and $29^{\text {th }}$ year of our rule over our other kingdoms. King Alfonso. 
ALMIR PECO

Aivo dince belline?

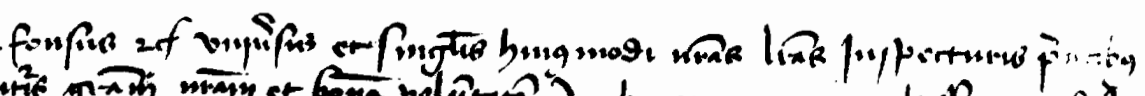

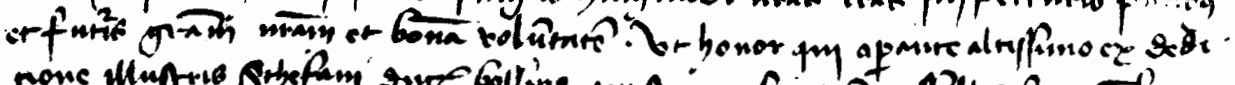

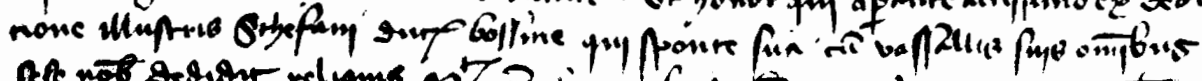

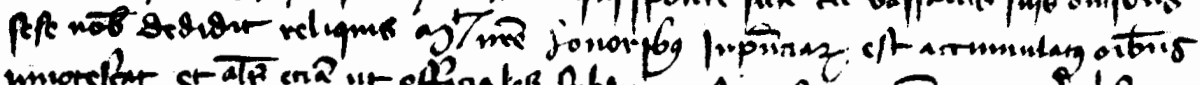

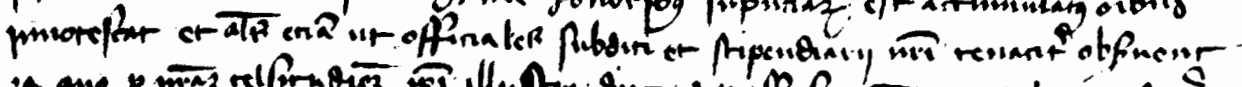

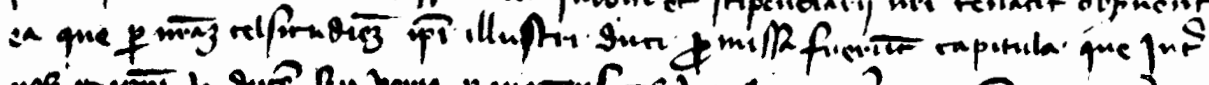

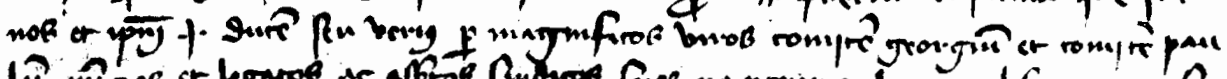

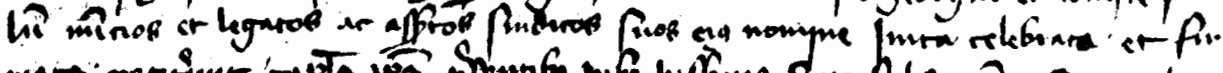

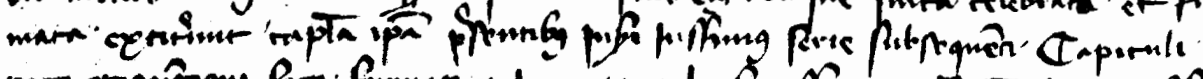

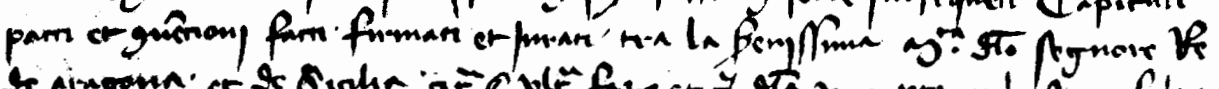

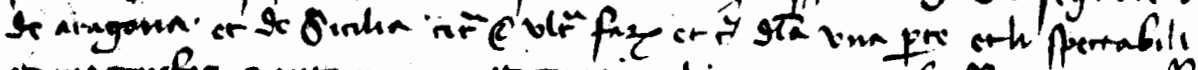

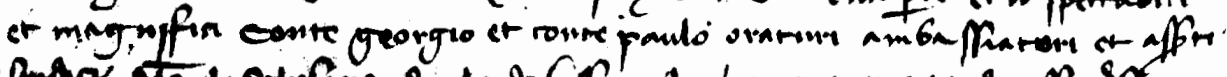

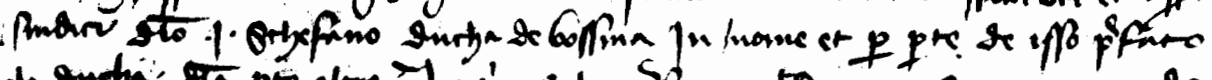

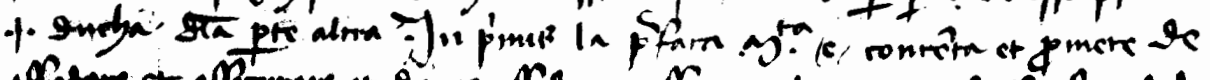

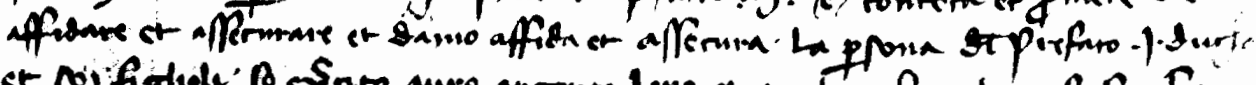

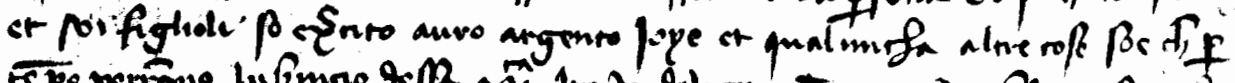

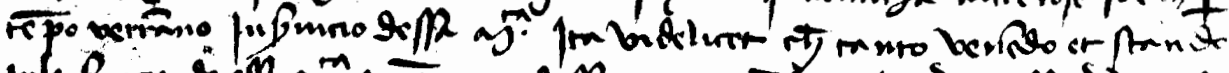

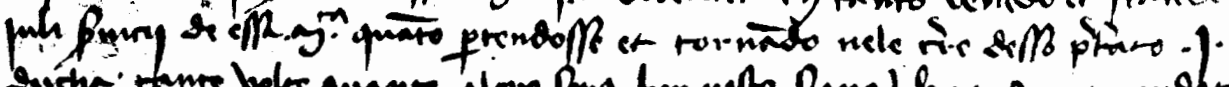

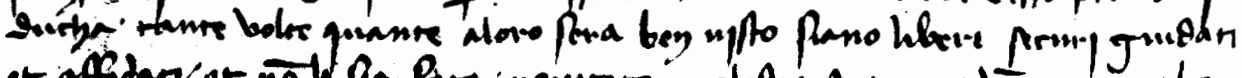

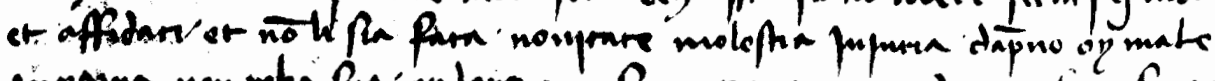

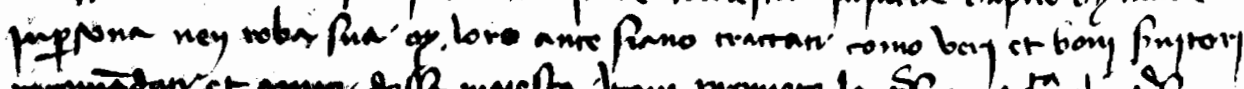

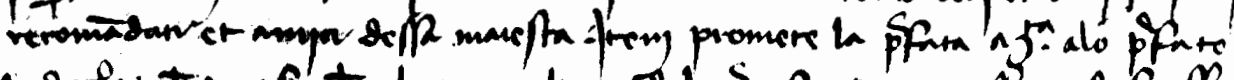

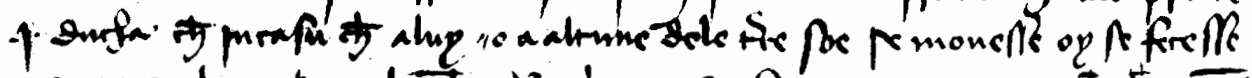

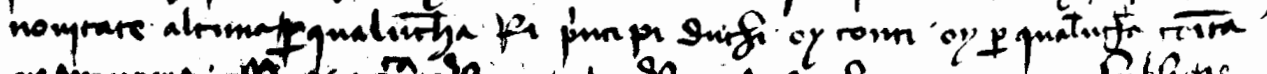

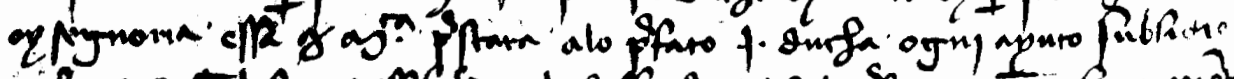

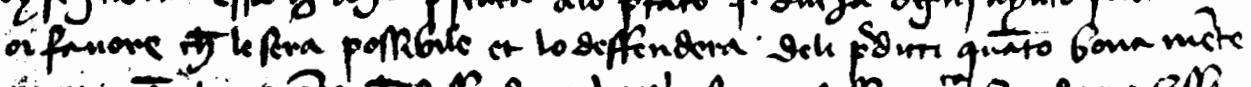

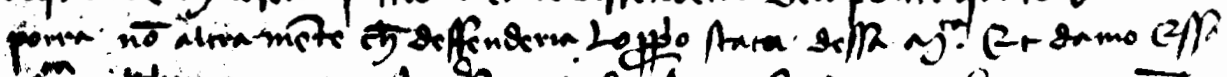

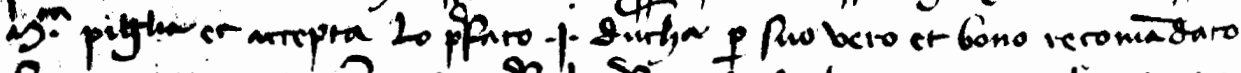

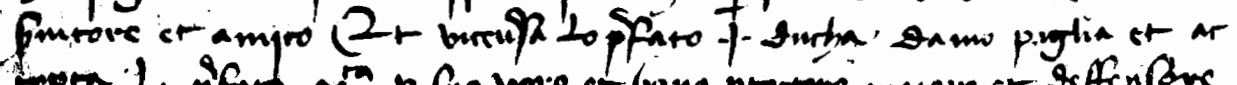

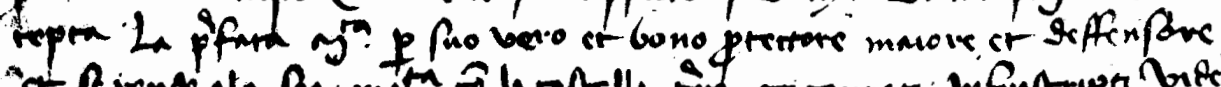

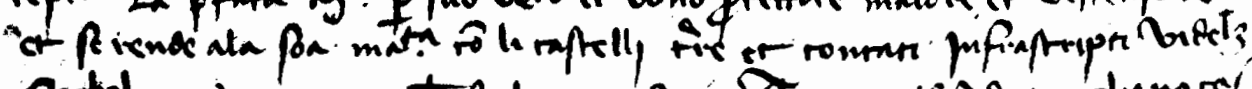

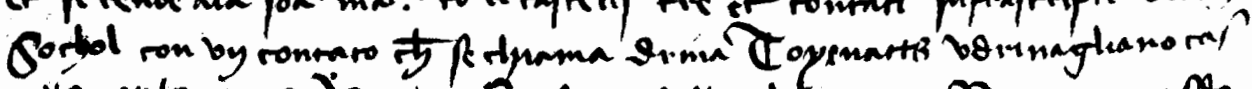

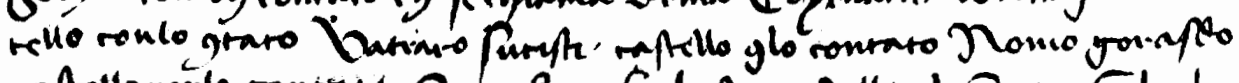

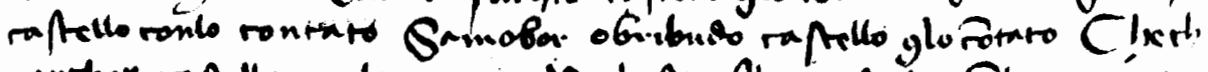

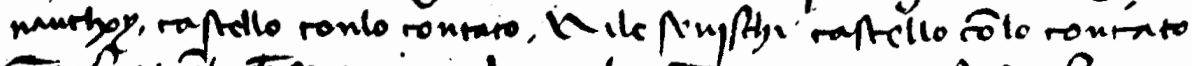

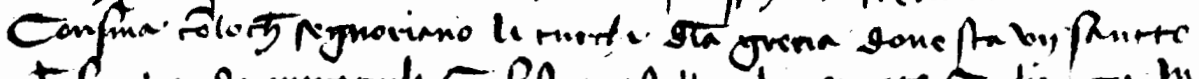

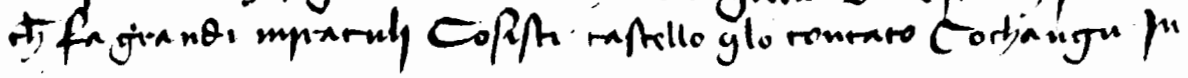

$\Rightarrow 90 \leqslant$ 


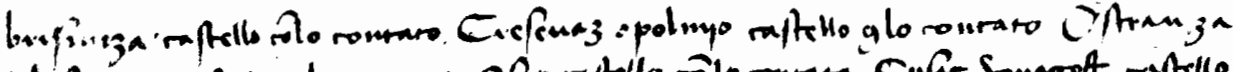

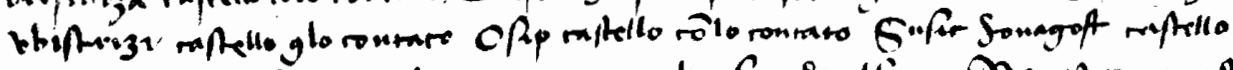

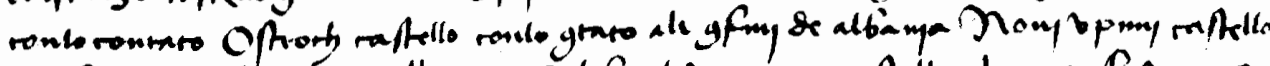

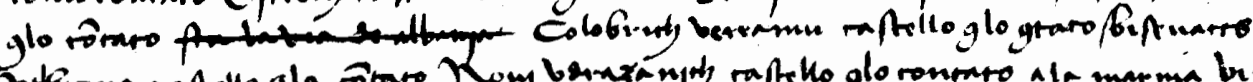

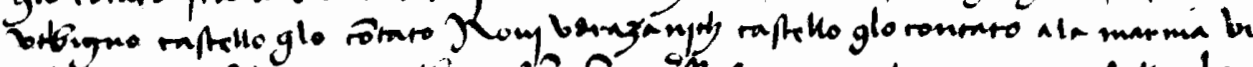

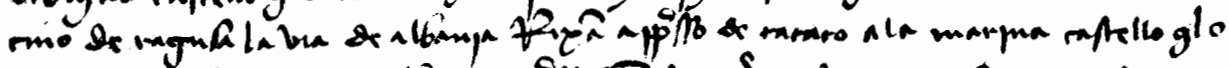

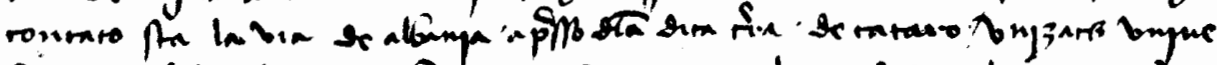

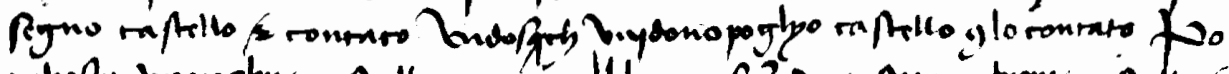

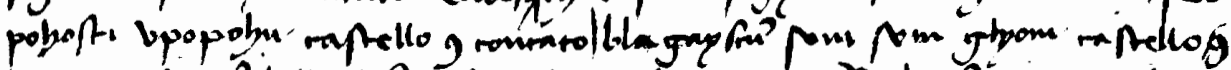

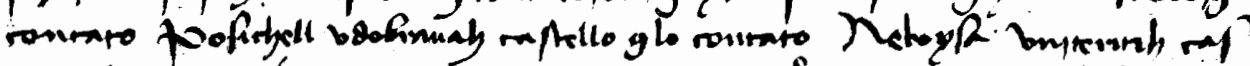

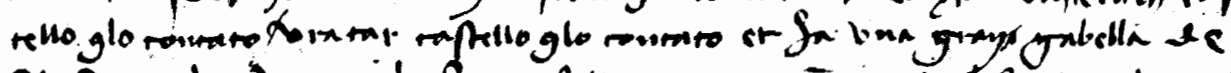

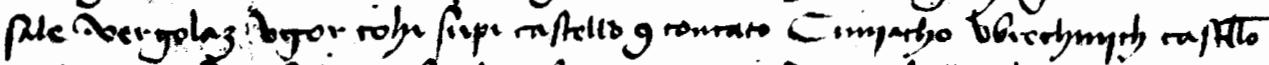

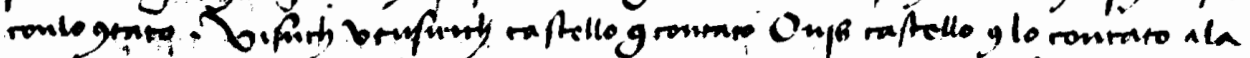

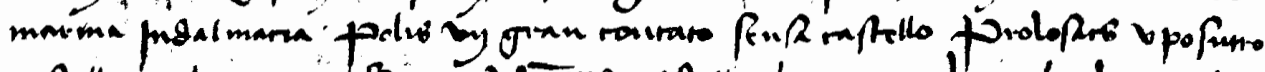

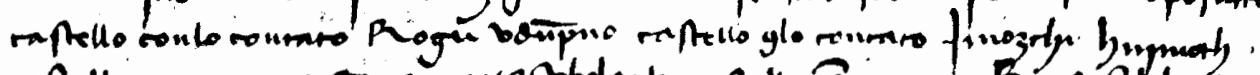

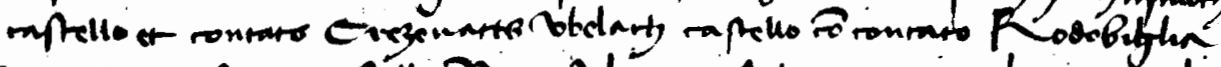

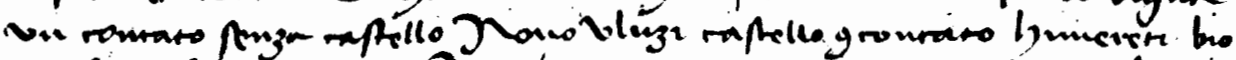

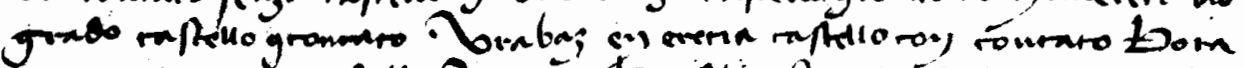

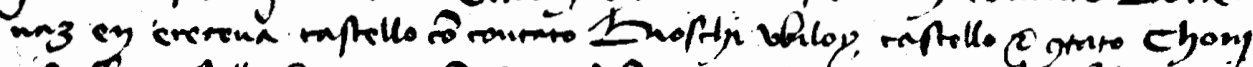

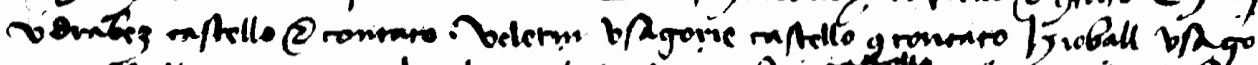

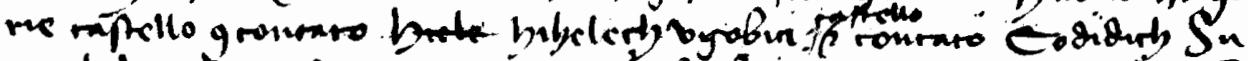

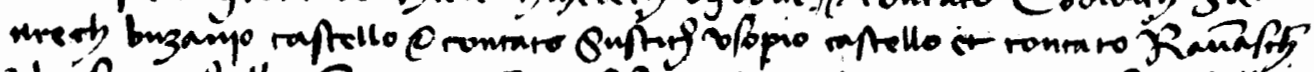

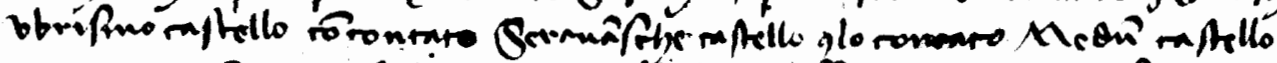

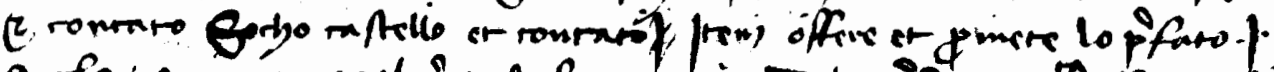

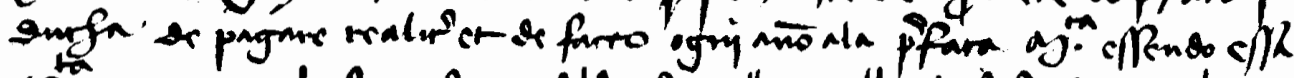

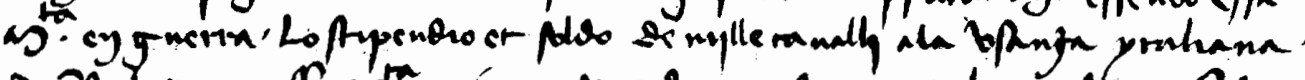

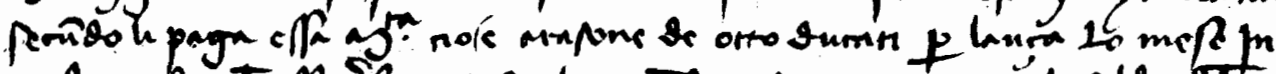

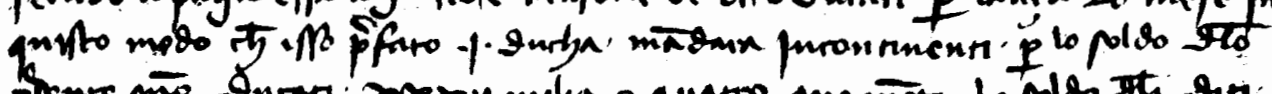

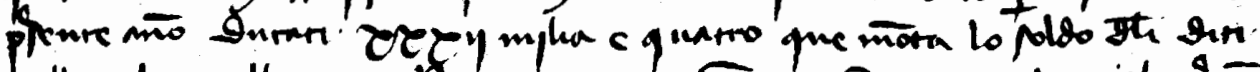

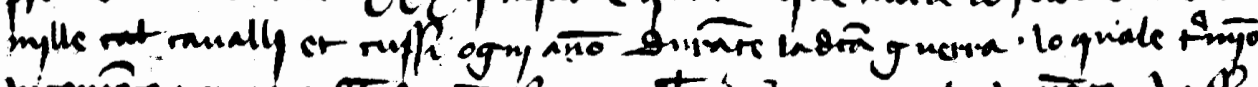

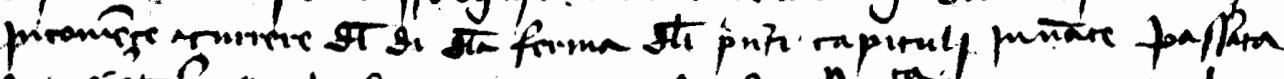

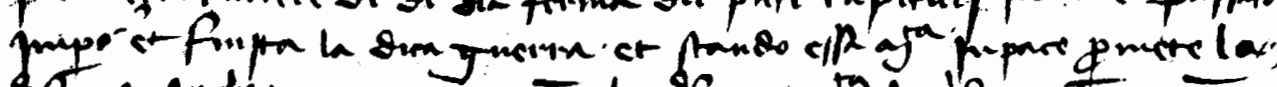

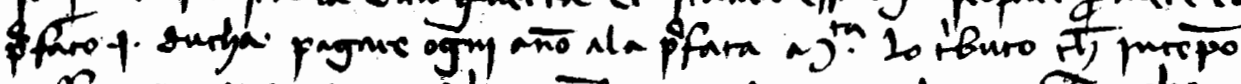

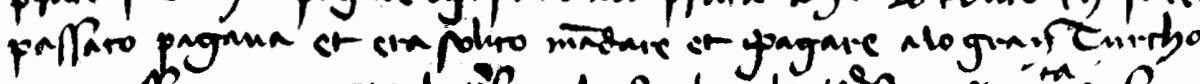

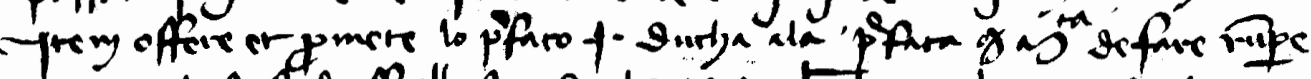

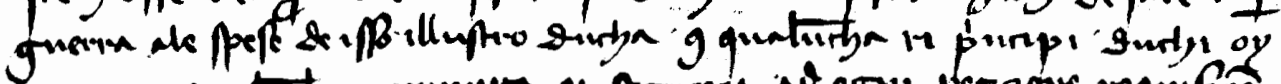

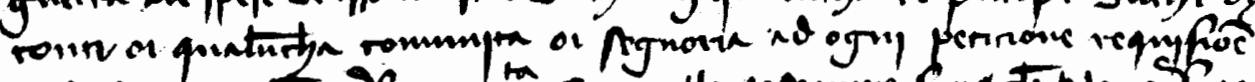

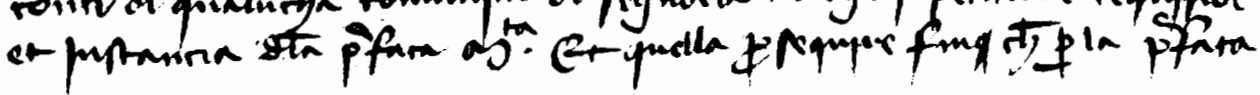




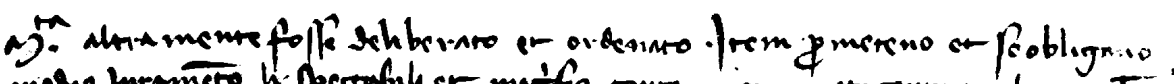

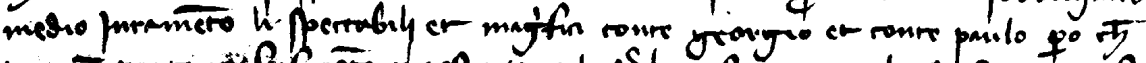

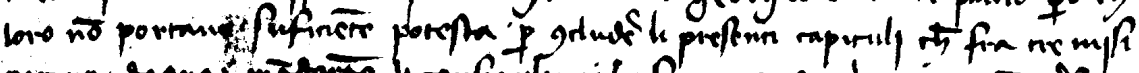

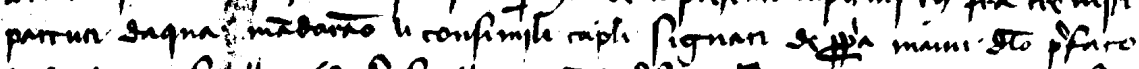

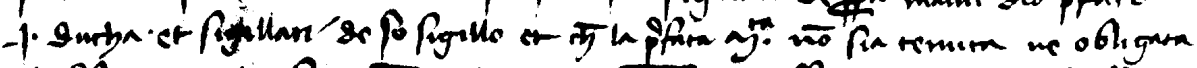

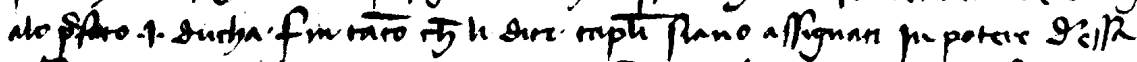

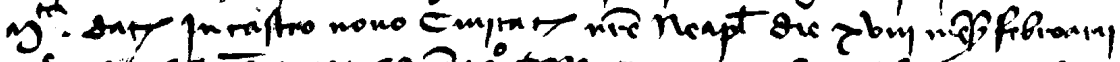

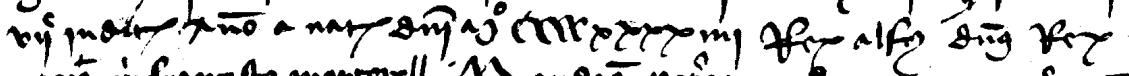

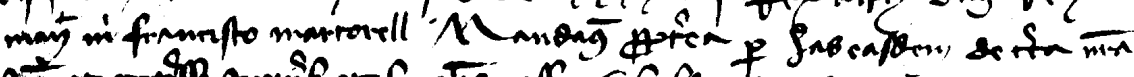

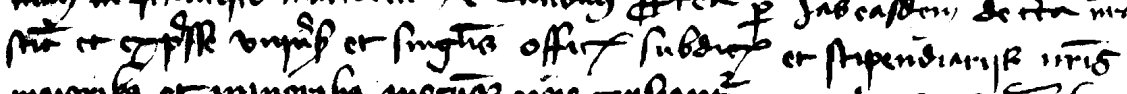

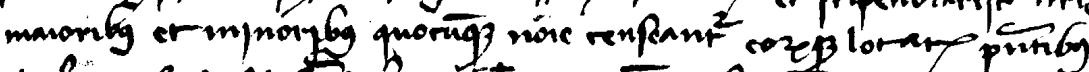

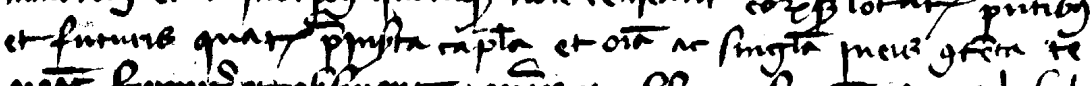

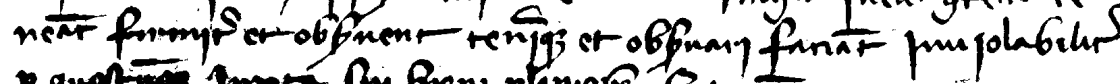

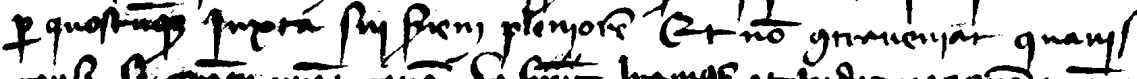

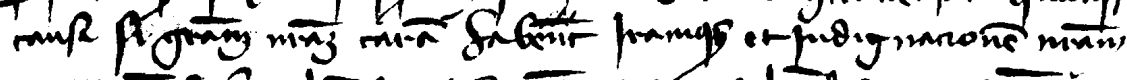

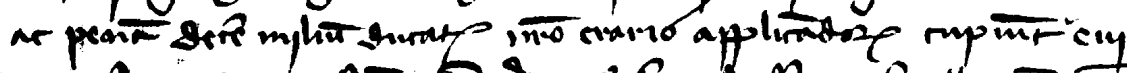

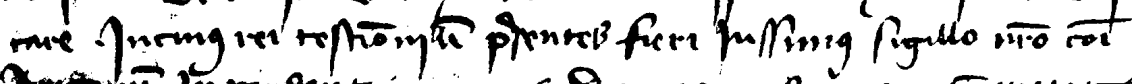

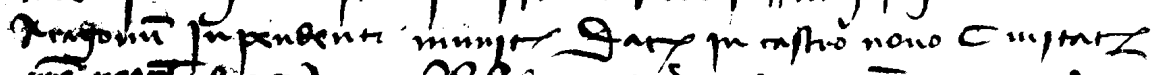

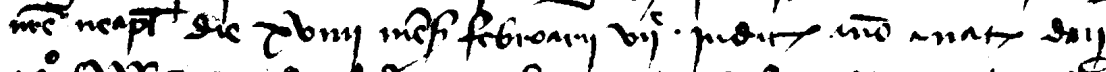

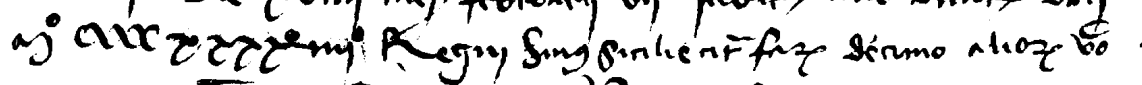

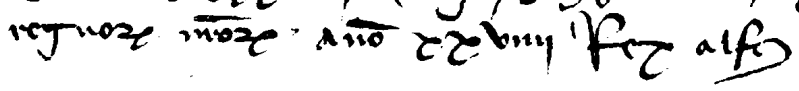

\section{Posent}

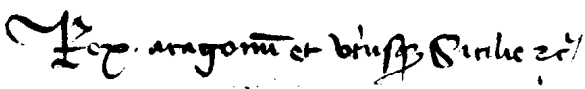

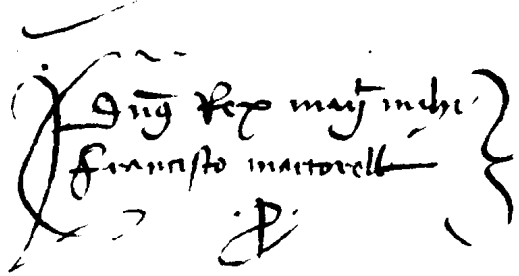

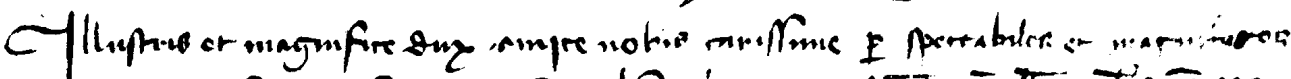

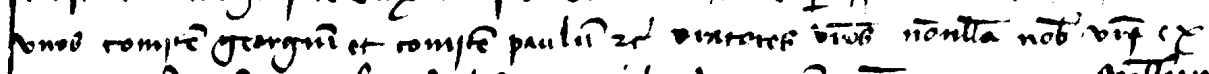

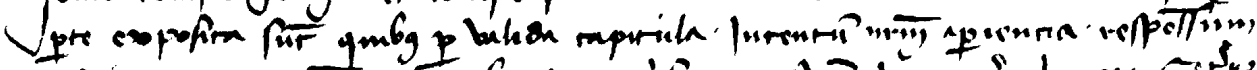

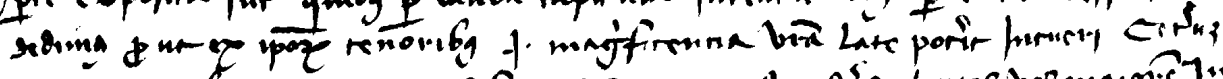

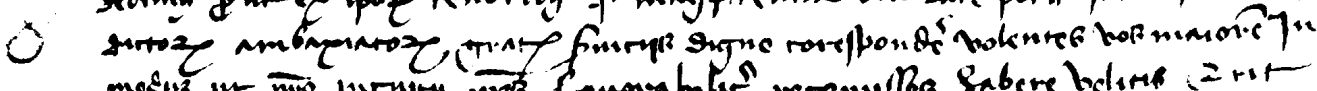

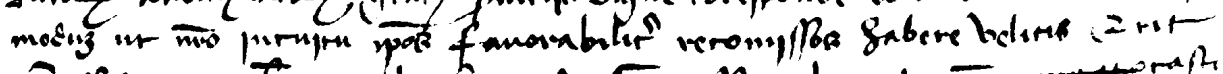

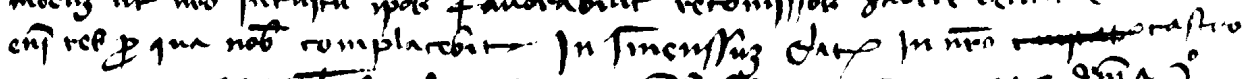

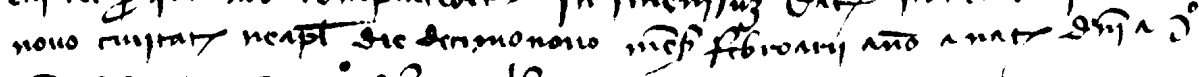
ancrezenij tres alfos

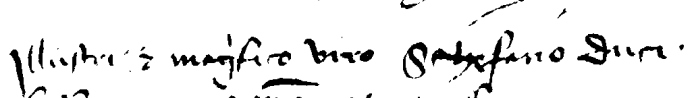

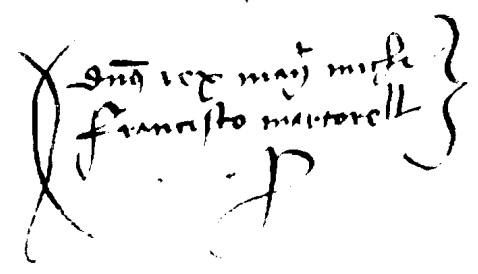




\section{Bibliography}

\section{Sources:}

Archivo de la Corona de Aragón, (ACA), CANCILLERÍA, Registros, NÚM. 2939.

Ljubić, Š. 1890, Listine o odnošajih između južnoga slavenstva i Mletačke Republike. IX, Zagreb: JAZU.

Thallóczy, L. 1914, Studien zur Geschichte Bosniens und Serbiens im Mittelalter. München und Leipzig: Duncker \& Humbolt.

\section{Literature}

Aloisio, M. 2017, Alfonso V and the anti-Turkish crusade. In: Housley, N. (ed.), The Crusade in the Fifteenth Century. Converging and competing cultures. London and New York: Routledge, 64-74.

Babić, A. 1960, Diplomatska služba u srednjovjekovnoj Bosni, Radovi Naučnog društva Bosne i Hercegovine XIII. Sarajevo, 11-70.

Ћирковић, С. 1961, “Верна служба” и “Вјера господска”, Зборник Филозофског факултета VI-2. БеограА, 321-322.

Ћирковић, С. 1964а, Херцег Стефан Вукчић - Косача и његово доба. Београд: Научно дело.

Ћирковић, С. 1964b, Историја средњовековне босанске државе. Београд: Српска књижевна заєруга.

Ćošković, P. 1988, Bosanska Kraljevina u prijelomnim godinama 1443-1446. Banja Luka: Institut za istoriju.

Аинић, М. 1940, Земье Херцега Светог Саве, ГАас Српске крањевске академије CLXXXII. БеограА, 151-257.

Аинић, М. 1978, Српске земье у средњем веку. Београд: Српска књижевна задруга. Filipović, E. O. 2019, Bosansko kraljevstvo i Osmansko carstvo (13861463). Sarajevo:

Orijentalni institut Univerziteta u Sarajevu.

Marinescu, C. 1994, La politique Orientale d'Alfonse v d'Aragon, roi de Naples (1416-1458).

Barcelona: Institut d'Estudis Catalans.

Острогорски, Г. 1959, Историја Византије. Београд: Српска књижевна задруга.

Premović, M. 2019, The Eastern Policy of Alfonso V the Magnanimous (of Aragon), Seen in the Light of His Political Relations with the Bosnian Duke-Herzog Stjepan Vukčić Kosača, Parergon 36/1. Perth, 81-106. 
Ryder, A. 1976, The Kingdom of Naples Under Alfonso the Magnanimous: The Making of a Modern State, Oxford: Clarendon press.

Ryder, A. 1990, Alfonso the Magnanimous: King of Aragon, Naples, and Sicily, 13961458.

Oxford: Clarendon press.

Спремић, М. 1971, Аубровник и Арагонци (1442-1495). Београд: Завод за издавање уџбеника Социјалистичке Републике Србије.

Спремић, М. 1974, Вазали краља А^фонса Арагонског, Зборник Фимозофског факултета

XII-1. БеограА, 455-469.

Спремић, М. 1985, Аеспот Ђурађ Бранковић и крањ А^фонс Арагонски, Зборник Фимозофског факултета XV-1. Београд, 127-143.

Тошић. Ђ. 1987, Трг Аријева у средњем вијеку. Сарајево: Васелин Маслеша.

Тошић, Ђ. 2002, Споредна грана племена Косача, Зборник за историју Босне и Хериеговине III. БеограА, 61-77.

Vego, M. 1978, Tri povelje o posjedima hercega Stjepana Vukčića Kosače, Most $\mathrm{V} / 19-20$.

Mostar, 123-142.

Vego, M. 1980, Tri povelje o posjedima hercega Stjepana Vukčića Kosače, in: Vego M., Iz historije srednjovjekovne Bosne i Hercegovine. Sarajevo: Svjetlost, 452486. 